\title{
PERCEPTION EFFECTS OF HIGH VOLTAGE TRANSMISSION (HVT) LINES ON RESIDENTIAL PROPERTY VALUES: CASES OF CHALALA, LIBALA SOUTH AND KAMWALA SOUTH AREAS OF LUSAKA CITY- ZAMBIA
}

\author{
Niraj Jain \\ The Copperbelt University-Zambia \\ e-mail:n_jain_zm@yahoo.co.uk \\ Roy A. Chileshe \\ The Copperbelt University-Zambia \\ e-mail:chilesher@yahoo.co.uk \\ Francis M Muwowo \\ The Copperbelt University-Zambia \\ e-mail: francismuwowo@yahoo.co.uk \\ Mambwe Mwewa
ZESCO Limited-Zambia
e-mail:misswreczz@gmail.com
}

Abstract
Although several recent studies have shown how high voltage transmission (HVT) lines affect
property values, no work has been undertaken in Zambia. This paper explores if there is a prima facie
relationship between HVT lines and residential property values in Zambia. A priori evidence shows a
paradox, with many new developments springing up in areas of high concentrations of HVT lines
though residents vehemently complain about the mal-effects of HVT lines. Why then should land
perceived to be inferior or "stigmatized" attract new developments? It is against this background that
the householders' perceptions of HVT lines are explored and the resulting effects on property values
ascertained. A household survey was conducted in the Chalala, Libala South and Kamwala South
areas of Lusaka city where developments have been undertaken around HVT Lines. The study also
examined the statistical relationship of distances from HVT line with residential property values.
Results show residential property values rise with increasing distance from the HVT line. It is
recommended that the statutory wayleave distances should be raised to at-least 100 meters from the
existing 31 meters for a 132kV line. It is further recommended that the regional wayleave guidelines
currently in use should be made national.

Key words: perception effects, high voltage transmission lines (HVT line), wayleaves, property values, electricity.

JEL Classification: Q51, R32, K11.

Citation: Jain N., Chileshe R.A., Muwowo F.M., Mwewa M., 2019, Perception Effects of High Voltage Transmission (HVT) Lines on Residential Property Values: Cases of Chalala, Libala South and Kamwala South Areas of Lusaka City-Zambia, Real Estate Management and Valuation, vol. 27, no. 3, pp. 31-41.

DOI: $10.2478 /$ remav-2019-0023 


\section{Introduction}

Traditionally, close distance to high voltage transmission lines has been associated with health and safety hazards (PRIESTLEY, EVANS 1990) such as: cardiovascular, digestive and central nervous system related diseases, leukemia in children, carcinogenesis, and cancer (see KHIZAR 1997, HARDELL et al. 1995). These associations, however, remain uncontested in this paper, as it is the effects on marketability of property arising from public perceptions (RICS 2003) of such lines that form the subject of this paper. Buyer (and tenant) dispositions towards the health \& safety risks and visual impacts of the HVT lines (HAMILTON, SCHWANN 1995) negatively affect property values (CALLANAN 2010). In fact, according to a Wayleave Report (ZESCO 2012), there has been an increase in the number of complaints on the perceived effects of HVT lines on the future values of residential properties in Lusaka. An empirical investigation thus becomes essential.

Similar studies can potentially benefit electrical companies in their HVT line routing plans (BOND, HOPKINS 2000) and in formulating wayleave guidelines. In the absence of objective wayleave guidelines, utility companies are drawn into expensive lawsuits. BOLTON provides an elaborate write-up on some legal implications of ambiguity in the wayleave guidelines (refer to some American cases, viz., San Diego Gas and Electric Co. v. Daley, Houston Lighting and Power Co. v. Klein Independent School District, Criscuola v. Power Authority of the State of New York, Ryan v. Kansas Power and Light Co. (BOLTON 1993). It is against this background that the paper seeks to explore the householders' perceptions of HVT lines on property values using a survey of residents in Chalala, Libala South and Kamwala South areas of Lusaka City.

\section{Literature review}

A cursory glance at literature shows diverse buyer (and tenant) perceptions of HVT lines. In some instances, financial concerns (e.g., difficulty obtaining a mortgage) and health \& safety risks (such as the perils of falling wires) are intrinsically linked with falling property values. Several early works, such as WerTHeIMER, LeEPER 1979; COLWELL, FOLEY 1979; SAVITZ et.al. 1988, KinNARD 1967 and CHALMERS, VOORVAART 2009, have sought to understand how HVT lines affect the health of occupants and thereon property values. A more thorough investigation using regression analysis on property specific characteristics and HVT line variables showed a negative impact on value (SIMS 2005). Houses within 50 meters of a pylon suffered the greatest loss in value, i.e. $£ 14,538.88$ compared to a paltry loss of $£ 1,817.36$ for a house situated 400 meters away.

KUNG and SEAGLE stated that "there are two ways in which power transmission lines may adversely affect property values or marketability" (KUNG, SEAGLE 1992). Firstly, HVT installations being easily noticeable are likely to raise anxiety in nearby communities (MITTENESS, MOONEY 1998). Secondly, the perceived association between being around HVT lines and the emergence of some adverse health effect precludes several buyers from participating in the market (DENT, SIMS 1999; GALLIMORE, JAYNE 1997; JAYNE 2000) thereby leading to "a decrease in demand for properties located near transmission lines" (KUNG, SEAGLE 1992). On the other hand, ROSIERS finds that being adjacent to a transmission line corridor does not necessarily diminish property values (ROSIERS 2002). In fact, a rise of $7 \%$ to $22 \%$ for the enlarged visual field and increased intimacy that goes along with it were discovered (ROSIERS 2002). These findings are consistent with those of SAINT-LAURENT 1996.

KINNARD et al. find no apparent price changes after a media coverage of EMF-induced health hazards in 1992 (KINNARD et al. 1997). BOTTEMILLER and WOLVERTON found a minimal negative price effect (of 1.4\% and 3.2\%) in two housing markets within the United States of America (BOTTEMILLER, WOLVERTON 2003).

A more recent study by AKINJARE et al. noted that residences within 0 to 50 meters suffered most in respect of rental value reduction, primarily from the fear of falling wires (AKINJARE et al. 2012). The buzzing/humming sound from an HVT line also had some influence on the final values. Property values diminished by as much as $20 \%$ when 15 meters away from a pylon, dropping to $5 \%$ at 50 meters from the pylon (BOND, HOPKINS 2000). Using the contingent valuation method (CVM), SERGIO et al. find that health risks of HVT lines are manifested in the visual impacts on landscape quality and the impact on the ecosystem (SERGIO et.al. 2010). Willingness to pay (WTP) estimates were generated for each of these impacts, ranging from $€ 101$ to $€ 188$, per household. It is further established that a high level of education is statistically significant in the perceived risks. 
ANDERSON, WILLIAMSON and WOHL provide an elaborate literature review of the HVT line studies undertaken in different regions as shown in Table 1 below (ANDERSON, WILLIAMSON, WOHL 2017).

Table 1

Effects of HVT lines on Property Values

\begin{tabular}{|c|c|c|c|}
\hline Author(s) & $\begin{array}{l}\text { Year(s) } \\
\text { of Study }\end{array}$ & $\begin{array}{l}\text { Study Composition } \\
\text { and Area }\end{array}$ & $\begin{array}{l}\text { Effects Found on Adjacent } \\
\text { Properties }\end{array}$ \\
\hline $\begin{array}{l}\text { BOTTLEMILLER, WOLVERTON } \\
\text { (2013) }\end{array}$ & $\begin{array}{l}2005 \text { to } \\
2007\end{array}$ & $\begin{array}{l}538 \text { house sales in areas } \\
\text { around Portland, } \\
\text { Oregon and Seattle }\end{array}$ & $\begin{array}{l}\text { Significant negative effects } \\
\text { found in Portland }(1.67 \%) \\
\text { and Seattle }(2.43 \%) .\end{array}$ \\
\hline $\begin{array}{l}\text { CHALMERS, VOORVAART } \\
(2009)\end{array}$ & $\begin{array}{l}1998 \text { to } \\
2007\end{array}$ & $\begin{array}{l}\text { Connecticut \& } \\
\text { Massachusetts }\end{array}$ & $\begin{array}{l}\text { No statistically significant } \\
\text { differences in prices } \\
\text { noticeable. }\end{array}$ \\
\hline MAY et al. (2011) & $\begin{array}{l}2000 \text { to } \\
2009\end{array}$ & $\begin{array}{l}1251 \text { Houses sold in } \\
\text { South London, UK }\end{array}$ & $\begin{array}{l}\text { House value increase of } \\
0.03 \% \text { with a } 1 \% \text { increase in } \\
\text { distance from HVT }\end{array}$ \\
\hline $\begin{array}{l}\text { JACKSON, PITTS, NORWOOD } \\
2012 \text { CITED IN ANDERSON, } \\
\text { WILLIAMSON, WOHL (2017) }\end{array}$ & $\begin{array}{l}2005 \text { to } \\
2010\end{array}$ & $\begin{array}{l}187 \text { commercial and } \\
\text { industrial properties in } \\
\text { Madison Wisconsin, US }\end{array}$ & $\begin{array}{l}\text { No significant negative } \\
\text { effects }\end{array}$ \\
\hline SIMS, DENT (2013) & $\begin{array}{l}1994 \text { to } \\
2010\end{array}$ & $\begin{array}{l}620 \text { house sales in } \\
\text { Blackwood, Scotland }\end{array}$ & $\begin{array}{l}\text { A price difference of } 21 \% \\
\text { observed between similar } \\
\text { properties at } 100 \mathrm{~m} \text { and } \\
400 \mathrm{~m} \text {. }\end{array}$ \\
\hline CALLANAN (2014) & $\begin{array}{l}1989 \text { to } \\
2010\end{array}$ & $\begin{array}{l}330 \text { properties before } \\
\text { removal of transmission } \\
\text { line and } 3345 \\
\text { afterwards in Newlands } \\
\text { suburb, Wellington, NZ }\end{array}$ & $\begin{array}{l}\text { A negative effect of } 27 \% \\
\text { found up to } 20 \mathrm{~m} \text { that } \\
\text { completely diminishes at a } \\
\text { distance of } 100 \mathrm{~m}\end{array}$ \\
\hline TATOS et al. (2016) & $\begin{array}{l}2001 \text { to } \\
2014\end{array}$ & $\begin{array}{l}125,000 \text { house sales in } \\
\text { Salt Lake County-Utah, } \\
\text { US }\end{array}$ & $\begin{array}{l}\text { The } 138 \mathrm{Kv} \text { line has the } \\
\text { greatest negative effect (of } \\
5.1 \% \text { ) for properties within } \\
50 \mathrm{~m}\end{array}$ \\
\hline
\end{tabular}

Source: Based on ANDERSON, WILLIAMSON, WOHL (2017).

DOUKAS et al. identify a number of pertinent variables including: "visual intrusion, transmission losses, noise, electromagnetic fields (EMF), infrastructure, interruption of supply, land use, ecosystems and property values" (DOUKAS et al. 2011, p. 981). However, not all variables are entirely responsible for the impact on property values. Literature tends to be polarized towards health and safety concerns. However, unsightliness, visual and aural pollution (SIMS, DENT 2005) tend to outweigh these concerns in the marketability of several properties. SIRMANS et al. recommend variables that are commonly used in housing studies (SIRMANS et al. 2005). Other studies have considered: the visual impacts (POHLMAN 1973), environmental attributes (KATZ 1971) including noise effects (MORGAN et al. 1985), biological impacts on birds' migratory paths (SIMS, DENT 2005), human health (BOYER et al. 1978) and diminished price, increased marketing time and decreased sales volume (KINNARD, DICKEY 1995).

\section{The Institutional and Legal Framework of Wayleaves in Zambia}

The principal legislations used in guiding and planning electrical installations include the Electricity Act of 1995 and the Energy Regulations Act of 1995; Local Government Act of 1991, the Urban and Regional Planning Act No. 3 of 2015, the Public Health Act Cap 295 of 1972, the Environmental Management Act No. 12 of 2011, Lands Act of 1995, and the Lands Acquisition Act of 1970- all of the laws of Zambia.

The Lands (Statutory Wayleaves) Act 1963 and the Electricity Act No. 15 1995, although they give no actual width indications, they provide for the acquisition of rights of ways. Acquisition of land for the purpose of electricity generation, transmission and distribution is governed by the Electricity 
(Amendment) Act Chapter 433 Part III (GRZ 1995a). Compensation is payable for land acquired for electricity generation and distribution. However, no compensation is payable for placing electricity installations such as high voltage transmission lines (HVT line) close to properties (GRZ 1995a).

The land allocation, approval of the transmission line proposals and registration is done by the Ministry of Lands, Deeds Registry Office (GRZ 1995b), once a relevant local authority/council recommendation. The wayleave sizes range from 31 meters to 50 meters, based on the voltages in the transmission lines (which vary between $66 \mathrm{kV}$ and $330 \mathrm{kV}$ ) (SAPP Environmental Sub-Committee 2010).

Table 2

Wayleave Sizes in Zambia

\begin{tabular}{lr}
\hline Transmission Lines & Wayleave Size on either side \\
\hline $\mathbf{3 3 0} \mathbf{~ K v}$ & 50 meters \\
\hline $\mathbf{2 7 5} \mathbf{~ K v}$ & 47 meters \\
\hline $\mathbf{1 3 2} \mathbf{~ K v}$ & 31 meters \\
\hline $\mathbf{8 8 ~ K v}$ & 31 meters \\
\hline $\mathbf{6 6} \mathbf{~ K v}$ & 31 meters \\
\hline $\mathbf{3 3} \mathbf{~ k V ~ ( H - P o l e )}$ & 31 meters \\
\hline $\mathbf{3 3} \mathbf{~ K v}$ & 22 meters \\
\hline $\mathbf{2 2} \mathbf{~ K v}$ & 15 meters \\
\hline
\end{tabular}

Source: SAPP Environmental Sub-Committee (2010).

In addition to the wayleave, the local authority has, in the past, planned residential areas in consultation with the Zambia Electricity Supply Corporation (now known as ZESCO) Limited keeping a buffer zone between residential properties and the transmission lines - a wayleave (LUSAKA CITY COUNCIL 2010).

\section{Data and methods}

Empirical data was acquired from a survey of households in Libala South, Kamwala South and Chalala areas of Lusaka where a $132 \mathrm{kV}$ HVT line passes. The three residential areas (Kamwala South, Libala South and Chalala) are amongst the recently planned residential neighborhoods in Lusaka with modern structures.

The wayleave passing through these areas comprises three $132 \mathrm{kV}$ HVT lines on towers (at 25 meters between parallel lines and 15 meters at both ends); and one $66 \mathrm{kV}$ overhead power line on wooden poles. The wayleave size for a single $132 \mathrm{kV}$ HVT line is 31 meters, i.e., 15 meters on either side of the towers and 1 meter around the tower structure. The power lines come from Leopards Hill Substation passing through Chalala to Lusaka Water Works Substation in Libala South and then cross Kamwala South to join Coventry Substation in the Central Business District of Lusaka (Map 1).

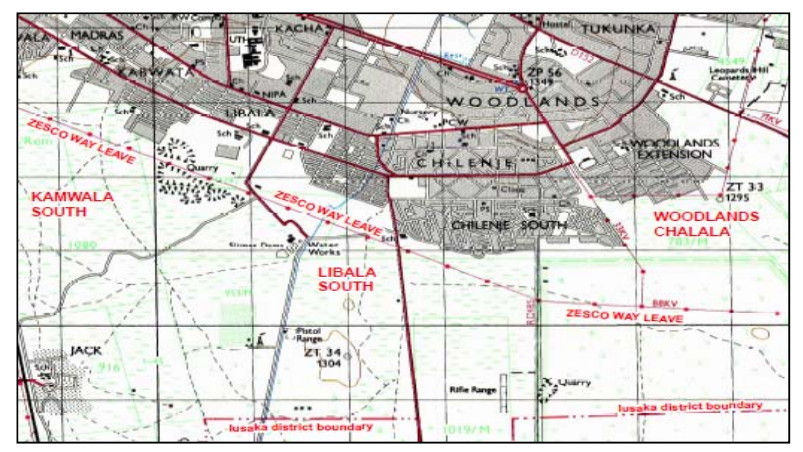

Map 1. Study Areas: Lusaka City- Libala South, Chalala and Kamwala South. Source: Lusaka City Council.

Chalala, Kamwala South and Libala South formed an important case study since several residents have expressed concerns to the Lusaka City Council over the diminution in their property values (ZESCO 2012). Questionnaires were administered to a calculated sample of 174 households (i.e., tenants/ landlords) at varying distances from the HVT line that were eventually categorized into three 
cohorts, viz., 32 to $50 \mathrm{~m}$; 51 to $100 \mathrm{~m}$; and 101 to $200 \mathrm{~m}$. In-depth interviews were also conducted with 10 real estate professionals (comprising of valuation surveyors, estate agents, property managers and property developers); and 5 officials (policy-makers and regulators) drawn from the Lusaka City Council and ZESCO Limited (Table 3).

Households were selected using the simple random sampling method but under the condition that property values were available for the selected unit of inquiry. In cases where property value data was not available, the field assistant systematically moved on to an adjacent property.

As for real estate professionals, only those that are registered with ZESCO Limited were considered.

Table 3

Study Units of Inquiry

\begin{tabular}{lllll}
\hline Ref. & Respondent/ Participants & Population & Sample & Response \\
\hline $\mathbf{0 1}$ & $\begin{array}{l}\text { Households (Libala South, Kamwala South and } \\
\text { Chalala) }\end{array}$ & $7291^{1}$ & $174^{2}$ & $104(60 \%)$ \\
\hline $\mathbf{0 2}$ & Real Estate Professionals & - & 10 & 10 \\
\hline $\mathbf{0 3}$ & $\begin{array}{l}\text { ZESCO Limited Officers (Environmental and Social } \\
\text { Affairs Wayleave Section and the Property }\end{array}$ & - & 5 \\
& $\begin{array}{l}\text { Department) and Lusaka City Council Officers } \\
\text { (City Planning, Valuation and Public Health } \\
\text { Departments) }\end{array}$ & & \\
\hline
\end{tabular}

${ }^{1}$ Based on Lusaka City Council records- Main Valuation Roll

2 Sampling based on SCHEAFFER et.al. 1979

Source: own study.

The study explored the following hypothesis: Null Hypothesis $\left(\mathrm{H}_{0}\right)$ : The householders' perceptions of high voltage transmission lines have no significant effect on the residential property values. And Alternate Hypothesis $\left(\mathrm{H}_{1}\right)$ : The householders' perceptions of high voltage transmission lines have a significant effect on the residential property values.

Property value data was acquired from "For Sale" adverts published in the local newspapers, registered estate agents and property valuers, seeing as how there is no central database. A smaller part of the values came from the Lusaka City Council Supplementary Valuation Roll. All subject properties were carefully chosen, and were characterized by similar use and building materials. Structural attributes (such as the size, number of bedrooms, presence of a boundary wall and garage/car port) and the distance from the HVT line formed the independent variables in this study (Table 4). These variables were studied using a linear regression function as shown in Equation 1. SPSS was used during the data analysis stage.

Table 4

Variable Definition and Classification

\begin{tabular}{lcccl}
\hline & Variable(s) & Equation Beta & Expected Sign & Definition \\
$\begin{array}{l}\text { Dependent } \\
\text { Variable }\end{array}$ & Property_Value & & & $\begin{array}{l}\text { Market Value of Residential } \\
\text { Property }\end{array}$ \\
\hline $\begin{array}{l}\text { Location } \\
\text { Attribute }\end{array}$ & Distance_HVT & $\beta_{1}$ & $+v e$ & $\begin{array}{l}\text { Distance From HVT lines } \\
\text { (square meters) }\end{array}$ \\
\hline $\begin{array}{l}\text { Structural } \\
\text { Attributes }\end{array}$ & Size_House & $\beta_{2}$ & +ve & Size of House \\
\hline & Bedroom_Nos & $\beta_{3}$ & +ve & Number of Bedrooms \\
\hline & Garage_Type & $\beta_{4}$ & +ve & $\begin{array}{l}\text { Presence and Number of } \\
\text { Garage }\end{array}$ \\
\hline & Fence_YN & $\beta_{5}$ & +ve & Presence of Boundary Wall \\
\hline
\end{tabular}

Source: own study. 
Equation 1 Study Regression Function (Linear):

$\operatorname{Pr}$ opertyValue $=\beta_{0}+\beta_{1}($ Dis tance_HVT $)+\beta_{2}($ Size_House $)+\beta_{3}($ Bedroom_Nos $)+\beta_{4}($ Garage_Type $)+\beta_{5}($ Fence_YN $)+\ell$

\section{Results and discussion}

\subsection{General background of respondents and participants}

\subsubsection{Employment status of householders}

The majority of the householders (66.3\%) are employed. A further 32.7\% of the respondents are selfemployed, whereas only $1.0 \%$ are unemployed (Table 5).

Table 5

Employment Status of Householders

\begin{tabular}{lrrr}
\hline & Frequency & $\begin{array}{r}\text { Percentage (\%) } \\
\text { Cumulative } \\
\mathbf{( \% )}\end{array}$ & $\begin{array}{r}\text { Cum } \\
\text { Civil Servant }\end{array}$ \\
Private companies & 28 & 26.9 & 26.9 \\
\hline Blue Collar Job (Pastor, tradesmen) & 38 & 36.5 & 63.5 \\
\hline Unemployed & 3 & 2.9 & 66.3 \\
\hline Self Employed & 1 & 1.0 & 67.3 \\
\hline Total & 34 & 32.7 & 100 \\
\hline
\end{tabular}

Source: own study.

\subsubsection{Length of employment - real estate professionals}

The real estate professionals consulted in this research have lengthy experience in the field of real estate and HVT lines. $40 \%$ of the interviewees had $10-15$ years of experience and $20 \%$ had more than 15 years of experience (Table 6). Hence, these individuals are well placed to respond on technical questions.

Table 6

Experience of Real estate professionals

\begin{tabular}{llrrr}
\hline Parameter & $\begin{array}{l}\text { Sub- } \\
\text { Division }\end{array}$ & Frequency & $\begin{array}{r}\text { Percentage(\%) } \\
\text { Years of professional Experience }\end{array}$ & $\begin{array}{r}\text { Cummulative } \\
(\mathbf{0})\end{array}$ \\
\hline & $\begin{array}{l}\text { Less than } \\
\text { 5years }\end{array}$ & 1 & 10 & 10 \\
\cline { 2 - 4 } & 5yrs - 10yrs & 3 & 30 & 40 \\
\cline { 2 - 4 } & Mors - 15yrs & 4 & 40 & 80 \\
\cline { 2 - 4 } & More than & 2 & 20 & 100 \\
\hline Total & & 10 & 100 & \\
\hline
\end{tabular}

Source: own study.

\subsection{Perceived effects of HVT lines}

Amongst the perceived effects of HVT lines, safety concerns scored the most (42.2\%). Householders had a fear of HVT cables breaking and falling onto their houses. However according to an in-depth interview with ZESCO Limited officials, the existing wayleave sizes are already large enough to account for any structural failures in the HVT lines and/or towers.

Health concerns were next in the line-up, with $28.9 \%$ responses. A lesser number was associated with noise concerns $(7.8 \%)$; most householders (76\%), expressed an unwillingness to occupy property near HVT lines on account of these concerns. Householders close to the HVT lines, in particular, had a negative perception. Interestingly, such resentments have become apparent after 2000, when the internet and electronic media outreach expanded rapidly (in-depth interview with Lusaka City Council officials). Nonetheless, such inhibitions can affect the demand for property (and finally its values). In fact, many real estate professionals experienced alleged difficulties in selling properties near HVT lines. 
Table 7

Perceived Effects of HVT lines

\begin{tabular}{lrrr}
\hline & Frequency & Percentage (\%) & Cumulative (\%) \\
\hline Noise concerns & 18 & 7.8 & 7.8 \\
\hline Visual unattractiveness & 49 & 21.1 & 28.9 \\
\hline Health concerns & 67 & 28.9 & 57.8 \\
\hline Safety concerns & 98 & 42.2 & 100.0 \\
\hline Total & 232 & 100 & \\
\hline
\end{tabular}

Source: own study.

Real estate professionals were largely polarized towards a combination of health \& safety concerns and visual unattractiveness as the perceived effects on residential property values. Similarly, officials from Lusaka City Council and ZESCO Limited believed that the health \& safety concerns and the visual unattractiveness of HVT lines played a major role in diminishing residential property values. The real estate professionals (and officials from Lusaka City and ZESCO Limited) could not, however, isolate any single dominant effect of HVT Lines. According to real estate professionals, residential property values decreased somewhere in the range of $0 \%$ to $5 \%$ as a result of a close-by HVT line.

\subsection{Reduction in residential property values from nearby HVT lines}

The regression results for the 104 properties showed a somewhat higher reduction, especially for properties located within 50 meters of HVT lines (i.e., $15.48 \%$ to $23.06 \%$ ). The residential property values tend to rise from one distance cluster to the next, as shown in Table 8 . The 32 to $50 \mathrm{~m}$ cluster that is closest to the HVT line has the least mean property values (K386,532.14) and the furthest cluster (101 to $200 \mathrm{~m}$ ) has the highest mean property value (K503036.54) (Table 8). The largest fall in property values $(23.06 \%)$ is found in the first distance cluster, i.e. 32 to $50 \mathrm{~m}$, which progressively drops to $15.48 \%$ in the next distance cluster, i.e. 51 to $100 \mathrm{~m}$.

Table 8

Property Values by Distance Cluster

\begin{tabular}{lrrr}
\hline $\begin{array}{c}\text { Distance } \\
\text { Cluster }\end{array}$ & $\begin{array}{r}\text { Mean Property } \\
\text { Values }\end{array}$ & $\begin{array}{r}\text { Fall in Mean Property Values } \\
\text { (Using 101 to 200 m as base) }\end{array}$ & $\begin{array}{r}\text { \% Fall in Mean } \\
\text { Property Values }\end{array}$ \\
\hline $32^{1}$ to $50 \mathrm{~m}$ & 386532.14 & 115835.36 & 23.0578929 \\
\hline 51 to $100 \mathrm{~m}$ & 502367.50 & 92026.94 & 15.4824699 \\
\hline 101 to $200 \mathrm{~m}$ & 594394.44 & - & - \\
\hline Average & 503036.54 & $\mathbf{1 0 3 9 3 1 . 1 5}$ & $\mathbf{1 9 . 2 7 0 1 8 1 4}$ \\
\hline
\end{tabular}

1 The existing wayleave size for the $132 \mathrm{kV}$ line is $31 \mathrm{~m}$.

Source: own study.

In order to ascertain if changes in the property values from one distance cluster to the next hold true for the population, an independent samples T-test was applied. And, in testing if the population means of the three distance clusters (32 to $50 \mathrm{~m}$; 51 to $100 \mathrm{~m} ; 101$ to $200 \mathrm{~m}$ ) are different with respect to property values, we find that, in each case, the significance level is less than 0.05 (Table 9), suggesting that the population means are different for the three distance clusters.

Independent Samples T-test Results (Distance Cluster/Property values)

Table 9

\begin{tabular}{lrrr}
\hline Distance clusters / Property values & Sig. (2-tailed) & N & Mean Difference \\
\hline 1 and 2 & .000 & 28 & -115835.357 \\
\hline 1 and 3 & .000 & 40 & -207862.302 \\
\hline 2 and 3 & .012 & 36 & -92026.944 \\
\hline
\end{tabular}

Relevant T-test Statistic based on Levene's Test for equality of variances

Source: own study. 


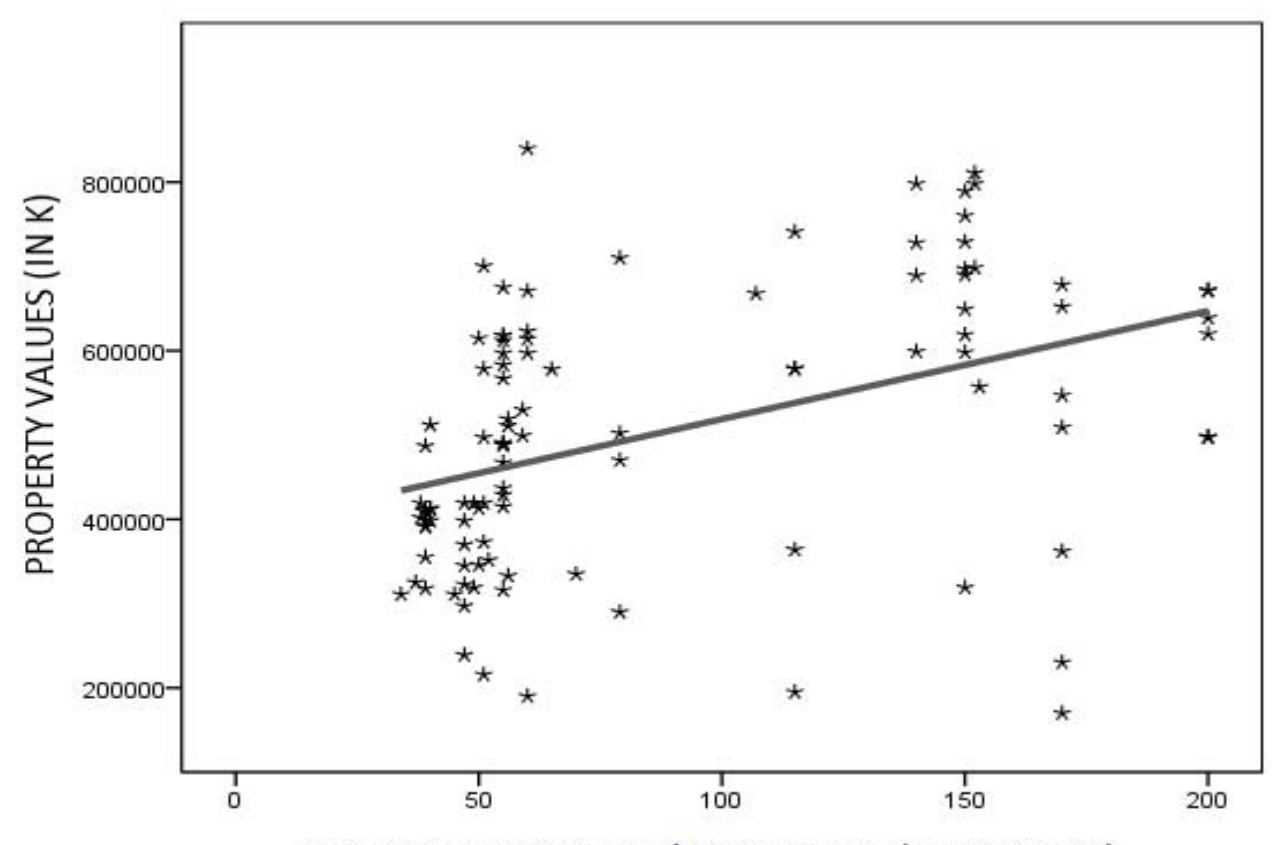

DISTANCE FROM 132kV HVT LINE (IN METERS)

Fig. 1. Property values by distance. Source: own study.

As part of the study hypothesis testing process (using multiple regression analysis), the adjusted $\mathrm{R}$ Squared was generated and found to be high (0.6531), suggesting that the five study variables are collectively a good predictor. However, when the variable for distance from HVT lines is removed, the regression shows a weak adjusted R Squared of 0.398 implying that the presence of nearby HVT lines does not affect residential property values.

The HVT line has a positive standardized coefficient of 0.513 (Table 10) (or 1,553.46 unstandardized) implying, ceteris paribus that the residential property values increase by K1, 553.46 for every meter of distance away from an HVT line. Arguably, a property 200 meters away from an HVT line will be K310,692 more valuable (or $61.8 \%$ above the average residential property value in the study area)! These findings are consistent with SIMS, DENT 2005. Any increase in the permitted wayleave sizes could substantially improve perceptions of people and hence, property values. In fact, most real estate professionals felt that the existing wayleave sizes were too small. Lusaka City Council and ZESCO Limited officials expressed similar sentiments.

Table 10

Regression Results

\begin{tabular}{|c|c|c|c|c|c|c|}
\hline \multirow{2}{*}{\multicolumn{2}{|c|}{ Model $^{1}$}} & \multicolumn{2}{|c|}{$\begin{array}{c}\text { Unstandardized } \\
\text { coefficients }\end{array}$} & \multirow{2}{*}{$\begin{array}{c}\begin{array}{c}\text { Standardized } \\
\text { coefficients }\end{array} \\
\text { Beta } \\
\end{array}$} & \multirow[t]{2}{*}{$\mathrm{T}$} & \multirow[t]{2}{*}{ Sig. } \\
\hline & & B & Std. Error & & & \\
\hline \multirow[t]{6}{*}{1} & (Constant) & 27511.073 & 98822.398 & & 278 & .781 \\
\hline & Distance_HVT & 1553.462 & 180.792 & .513 & 8.593 & .000 \\
\hline & Size_House & -1427.853 & 340.943 & -.582 & -4.188 & .000 \\
\hline & Bedroom_Nos & 229579.228 & 25901.906 & 1.203 & 8.863 & .000 \\
\hline & Type_Garage & 12739.837 & 16204.201 & .054 & .786 & .434 \\
\hline & YN_Fence & -25122.322 & 19339.020 & -.077 & -1.299 & .197 \\
\hline
\end{tabular}

${ }^{1}$ Dependent Variable: Property_Value

Source: own study.

In testing the study hypothesis, a t-test was conducted on the slope coefficient of the "Distance_HVT" (distance from HVT lines) variable. At a 95\% confidence $(\alpha=5 \%)$, the calculated $t$ stat of 8.593 is higher than the critical value of 1.984 . Thus, the null hypothesis $\left(\mathrm{H}_{0}\right)$ is rejected in favor 
of the alternate hypothesis $\left(\mathrm{H}_{1}\right)$, implying that: "householders" perceptions regarding high voltage transmission lines have a significant effect on residential property values.

\subsection{Challenges in creating and managing wayleaves and buffer zones}

It was revealed during in-depth interviews that, besides paying attention to wayleave sizes, the Council ought to collaboratively plan for buffer zones between HVT lines and residential properties, as was the case in the past. Lusaka City Council officials further stated that the two organizations should liaise not only in planning, but also monitoring, controlling and regulating developments in areas where HVT lines traversed over residential properties, and that the use of a mutually operated GIS platform was apt for these purposes.

Many challenges emerged from the in-depth interviews. Physical standards, regulations, guidelines and planning policies were oftentimes compromised in the drive for creating more residential plots. Noticeably, many individuals encroached into areas earmarked for buffer zones. The wayleave guidelines currently in use are from the Southern African Power Pool (SAPP) with absolutely no specific consideration of the local planning conditions.

\section{Conclusion and Recommendations}

Literature shows diverse perceptions of HVT lines on residential property values. In some instances, a positive effect is noticeable (see ROSIERS 2002) while in others, a negative effect has been found (see SIMS 2005). However, in Zambia, the effects of HVT lines on residential property values have remained unclear. This study therefore sought to use the cases of Chalala, Libala South and Kamwala South residential areas of Lusaka City (where a 132kV HVT Line passes through) to investigate how HVT lines affect property values. The findings from this research are twofold, pertaining to: the householders' perceptions of the effects of HVT lines and the empirical relationship between the distance from HVT lines and property values. A number of inferences can be made: firstly, safety concerns are the principal perceived effect of HVT lines; secondly these effects have a statistically significant relationship with residential property values. Residential properties, particularly those within 50m of HVT lines, are most affected with a progressively lower effect as distance rises.

It is recommended that the power utility company (ZESCO Limited) should, in partnership with the local authority (Lusaka City Council), develop a common GIS Mapping database that shows existing and future transmission line development plans. This will assist in planning residential areas with minimal effects from HVT lines. The council should also create buffer zones between the wayleaves and the nearest residential properties.

In reviewing the wayleave sizes, the two above-mentioned organizations should collaborate in identifying optimum wayleave sizes based on anticipated value impacts (and not just the falling distance of towers). Based on the study findings, a minimum distance of $100 \mathrm{~m}$ for a $132 \mathrm{kV}$ line is proposed. Finally, the wayleave regulations and general guidelines for transmission line infrastructure should become nationwide, paying particular attention to the local planning conditions.

\section{References}

AKINJARE O., OluWUNMI A., IrOHAM C., 2012, Impact of HVOTLs on Residential Property Rental Values in High-Brow Lagos Metropolis, Ethiopian Journal of Environmental Studies and Management, vol. 5 no. 1, http://dx.doi.org/10.4314/ejesm.v5i1.7 (Access date: 09.07.2018).

ANDERSON O.C., WilliamsOn J., WOHL A., 2017, The Effect of High-Voltage Overhead Transmission Lines on Property Values: A Review of the Literature Since 2010, The Appraisal Journal, Summer 2017.

Bolton D., 1993, Properties near Power Lines and Valuation Issues: Condemnation or Inverse Condemnation? Institute on Planning, Zoning and Eminent Domain, Municipal Legal Studies Center, Dallas, Texas, November 17-19.

BOND S., HOPKINS J., 2000, The Impact of Transmission Lines on Residential Property Values: Results of a case Study in a Suburb of Wellington, The Pacific Rim Property Research Journal, vol. 6 no. 2, pp 52-60.

BOtTEMILLER S.C., WOLVERTON M.L., 2013, The Price Effects of HVTLs on Abutting Homes, The Appraisal Journal 81, No. 1, Winter, https://www.nar.realtor/sites/default/files/ reports/2013/PriceEffects-of-High-Voltage-Lines-March-2013.pdf (Access date: 09.07.2018).

BOYER J.C., Mitchell B., FENTON S., 1978, The Socio-economic impacts of electric transmission corridors: A comparative analysis, Royal Commission on Electric Power Planning, University of Waterloo, Waterloo. 
Callanan J., 2010, An Update on the Latest Literature - The Effect of High Voltage Overhead Transmission Lines on Property Values, 16th Pacific Rim Real Estate Conference 24 - 27 January, 2010, Wellington, New Zealand.

CAllanAN J.M., 2014, Assessing the Property Market Impact of Stigma Removal: High Voltage Overhead Transmission Lines Removal in Wellington, NZ (Doctoral Thesis, Queensland University of Technology), https://eprints.qut.edu.au/71885/2/Judith_Callanan_Thesis.pdf (Access date: 09.07.2018).

Chalmers J.A., VOORVAart F.A., 2009, High Voltage Transmission Lines: Proximity Visibility and Encumbrance Effects, The Appraisal Journal, pp 227-245.

COLWELl P.F., FOLEY K.W., 1979, Electric transmission lines and the selling price of residential real estate, The Appraisal Journal, October, pp 490-499.

Des-RosiERS F., 2002, Power Lines, Visual Encumbrance and House Values: A Micro-Spatial Approach to Impact Measurement, Journal of Real Estate Research, vol. 23 no. 3, pp 275-301.

Doukas H., Karakosta C., Flamos A., PsarRas J., 2011, Electric Power Transmission: An Overview of Associated Burdens, International Journal of Energy Research, vol. 35 no. 11, pp 979-988.

GAllimore P., JAYNE M., 1997, Public and professional perceptions of high voltage transmission line risks: avoiding circularity, RICS Cutting Edge Proceedings, RIC, London-UK.

GRZ, 1963, Lands (Statutory Wayleaves) Act, Cap 186 of the Laws of Zambia, Lusaka: Government Printers

GRZ, 1970a, Lands Acquisition Act, Cap 189 of the Laws of Zambia, Lusaka: Government Printers

GRZ, 1970b, Lands and Deeds Registry Act, Cap 185 of the Laws of Zambia, Lusaka: Government Printers

GRZ, 1972, Public Health Act, Cap 295 of the Laws of Zambia, Lusaka: Government Printers

GRZ, 1991, Energy Regulation Act, Cap 436 of the Laws of Zambia, Lusaka: Government Printers

GRZ, 1991, Local Government Act, Cap 281 of the Laws of Zambia, Lusaka: Government Printers

GRZ, 1995a, Electricity Act, Cap 433 of the Laws of Zambia, Lusaka: Government Printers

GRZ, 1995b, Lands Act, Cap 184 of the Laws of Zambia, Lusaka: Government Printers

GRZ, 2011, The Environmental Management Act, No 12 of the Laws of Zambia, Lusaka: Government Printers

GRZ, 2015, Urban and Regional Planning Act, No 3 of the Laws of Zambia, Lusaka: Government Printers

Hamilton S.W., ScHWANN G.M., 1995, Do High Voltage Electric Transmission Lines Affect Property Value? Land Economics, vol. 71 no. 4, pp 436-44.

Hardell, Holmberg B., Malker H., PAulsson L.E., 1995, Exposure to Extremely Low Frequency Electriomagnetic Fields and the Risk of Malignant Diseases- An Evaluation of Epidemiological and Experimental Findings, Euro Journal on Cancer (Supplement 1).

JACKSON T.O., PITTS J., 2010, The Effects of Electric Transmission Lines on Property Values: A Literature Review, Journal of Real Estate Literature, vol. 18 no. 2, http://www.atc-projects.com/wpcontent/uploads/2012/11/2010-Jackson-The-Effects-of-Electric-Transmission-Lines-on-PropertyValues.pdf (Access date: 09.07.2018).

JAyne M.R., 2000, High Voltage Overhead Lines and Public Perceptions of Risk: A Report Power Lines and Property Values, RICS Research Foundation, London.

KATZ M., 1971, Decision-Making in the Production of Power, Scientific American, vol. 224 no. 3, pp 191200.

KHIZAR W., 1997, Monitoring of Ongoing Research on the Health Effects of High Voltage Transmission Lines (12 ${ }^{\text {th }}$ Annual Report), An annual report submitted to the Virginia General Assembly, 1997 Session pursuant to Senate Joint Resolution No. 126 of the 1985 Session and Senate Joint Resolution No. 278 of the 1993 Session.

KinNaRd W.H., Geckler K., Kinnard J., Mitchell P., 1984, An analysis of the impact of high voltage electric transmission lines on residential property values in Orange County, New York, A report prepared for the Real Estate Counseling Group of Connecticut, May 1984.

KINNARD W.N. JR., DiCKeY S.A., 1995, A Primer on Proximity Impact Research: Residential Property Values Near High - Voltage Transmission Lines, Real Estate Issues Magazine, April 1995, New York, USA.

KINNARD W.N., 1967, Power lines and residential property values, The Appraisal Journal, April, pp 269284.

Kung H.T., SeAgle C., 1992, Impact of Power Transmission Lines on Property Values: A Case Study, The Appraisal Journal, pp 413-418. 
LuSAKA City COUNCIL (LCC), 2010, Public health Assessment Report on The Impacts of ZESCO Power Transmission Lines on the Health of People In Lusaka City. The Pan African Council of Local Governments Summit on 20th December 2010, Johannesburg, South Africa.

MAY D.E., CORBIN A.R., Hollins P.D., 2011, Identifying Determinants of Residential Property Values in South London, Review of Economics Perspectives, vol. 11, no. 1, pp 3-11.

MitTeness S., MoONEY C., 1998, Power-line perceptions: their impact on market time, Paper presented at American Real Estate Society, Monterey, California, April 1998.

Morgan M., PukKala E., KAPRIO J., 1985, Power Line Frequency Electric and Magnetic Fields: a pilot study of risk perception, Risk Analysis, vol. 5 no.2, pp. 139-149.

MOULDER J.E., FOSTER K.R., 1995, Biological Effects of Power-frequency fields as they relate to Carcinogenesis - Mini Review, Proc Soc Exp Biol Med Journal, pp. 309-324.

NAIR I., MORGAN M.G., FLORIG H.K., 1989, Biological effects of power frequency electric and magnetic fields, Background paper, Washington DC, US.

Pohlman J.C., 1973, What is the Public 's Opinion on Transmission Towers and Poles? Electric Light and Power, pp 59-61.

Priestley T., EVANS G., 1990, Perception of a Transmission Line in a Residential Neighborhood: Results of a Case Study in Vallejo, California, A report prepared for the Southern California Edison Environmental Affairs Division.

RICS 2003, RICS Appraisal and Valuation Standards, Royal Institution of Chartered Surveyors, London.

Rosiers F.D., 2002, Power Lines, Visual Encumbrance and House Values: A Micro-Spatial Approach to Impact Measurement, Journal of Real Estate Research, vol. 23 no. 3.

SAINT-LAURENT J., 1996, Evaluation de l'exposition résidentielle aux champs électromagne'tiques ge'ne're's par une ligne a' haute tension et perceptions des risques potentiels, Master's thesis, Laval University, September 1996.

SAPP ENVIRONMENTAL SUB-COMMITTEE 2010, SAPP Environmental and Social Impact Assessment Guidelines for Infrastructure Development, Southern African Power Pool Configuration Management Review, Johannesburg, South Africa.

SAvitz D.A., WACHTEl H., BARneS F.A., John E.M., TvRDIK J.G., 1988, Case Control Study of Childhood Cancer and Exposure to 60-Hz Magnetic Fields, American Journal of Epidemiology, vol. 128 issue 1, pp 21-38.

SCHEAFFer R.L., MENDENHALl W., OtT L., 1979, Elementary Survey Sampling, Duxbury Press, North Scituate, Massachusetts.

Sergio G., Vito F., SilvanA D., 2010, Who's Afraid of Power Lines? Merging Survey and GIS Data to Account for Spatial Heterogeneity, Working paper, Department of Economics, University of Turin, Italy.

SIMS S., DENT P., 2013, HVOTLs in the UK, In Towers, Turbines and Transmission Lines: Impact on Property Value, Wiley- Blackwell, West Sussex, UK, pp 55- 79.

SIMS S., DENT P., 2005, High-voltage overhead power lines and property values: a residential study in the UK, Urban Studies, vol. 42 no. 4, pp 665-694.

SIMS S.C, 2005, Power lines and house prices: Real versus Perceived Impacts, Paper presented at the ENHR Conference 20 ${ }^{\text {th }}$ Date 2005, Oxford Brookes University, Oxford.

SIRMANS S., MACPHERSON D., ZIETZ E., 2005, The Composition of Hedonic Pricing Models, Journal of Real Estate Literature, vol. 13 no. 1, pp 3-42.

TAtos T., Glick M., LunT T.A., 2016, Property Value Impacts from Transmission Lines, Sub-transmission Lines, and Substations, The Appraisal Journal, Summer, pp 205- 230.

WERTHEIMER N., LEEPER E., 1979, Electrical wiring configurations and childhood leukemia in Rhode Island, American Journal of Epidemiology, pp 273-284.

ZESCO 2012, Annual wayleave report on the management and maintenance of wayleaves for ZESCO Limited, Environment and Social Affairs Unit (ESU), Lusaka. 